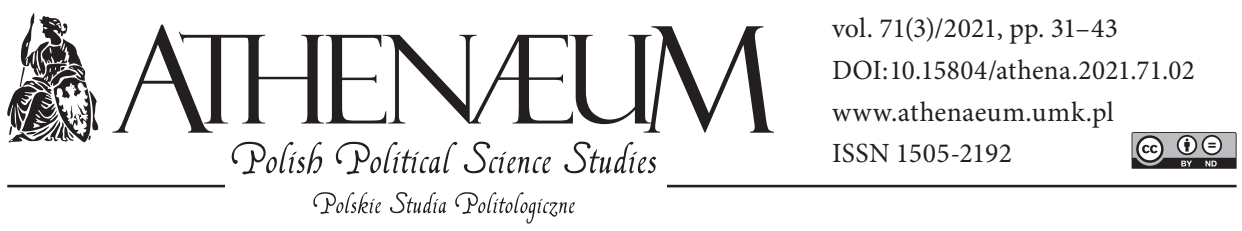

\title{
THE POLITICAL MYTH OF CORNELIU ZELEA CODREANU IN THE THOUGHT OF CONTEMPORARY POLISH NATIONALIST GROUPS
}

\author{
MIT POLITYCZNY CORNELIU ZELEI CODREANU \\ W MYŚLI WSPÓŁCZESNYCH POLSKICH UGRUPOWAŃ \\ NACJONALISTYCZNYCH
}

Marcin Pisarski*

\begin{abstract}
The article presents the issue of influence of the political myth of Corneliu Zelea Codreanu on the thought of contemporary Polish nationalist groups. The Legionary Movement is a particular example of combining a strong religious commitment with political extremism. The figure of Codreanu is one of the most frequently invoked in the discourse of contemporary nationalist groups. The aim of this article is to show the influence of the Codreanu myth on the political thought of four contemporary Polish groups: National Revival of Poland, All-Polish Youth, National-Radical Camp, and Falanga. As a result of the analysis of the content presented by the groups mentioned above, the political myth of Codreanu can be considered the most popular personal political myth of contemporary Polish as well as European nationalism.
\end{abstract}

Keywords: Corneliu Zelea Codreanu; Iron Guard; political myth; nationalism; tercerism (Third Position ideology)
Artykuł prezentuje zagadnienie oddziaływania mitu politycznego Corneliu Codreanu na myśl współczesnych polskich ugrupowań nacjonalistycznych. Ruch Legionowy jest szczególnym przykładem religijnego zaangażowania $\mathrm{w}$ polityce. Postać Codreanu pokazuje funkcjonowanie mitu politycznego w dyskursie współczesnych ugrupowań nacjonalistycznych. Celem artykułu jest ukazanie wpływu mitu Codreanu na myśl polityczną czterech współczesnych polskich ugrupowań: Narodowego Odrodzenia Polski, Młodzieży Wszechpolskiej, Obozu Narodowo-Radykalnego oraz Falangi. W wyniku analizy treści prezentowanych przez wymienione ugrupowania można uznać mit polityczny Codreanu za najpopularniejszy personalny mit polityczny współczesnego polskiego, ale i europejskiego nacjonalizmu.

Słowa kluczowe: Corneliu Zelea Codreanu; Żelazna Gwardia; mit polityczny; nacjonalizm; terceryzm

* University of Zielona Góra, Institute of Political Science and Administration. 


\section{INTRODUCTION}

Among twentieth-century political movements, nationalism was most strongly associated with Christianity. The conservative right wing saw religion as the guardian of tradition, while nationalism saw a way in it to raise a new man a citizen of the nation-state. The Romanian legionary movement, and in the context of the article, the political myth of the Iron Guard leader, is a particular example of the combination of nationalism and religion (Pisarski, 2015, pp. 251-260). The myth of Codreanu, the political martyr of Romanian nationalism, was at the heart of the declaration of Romania as a "National Legionary State" two years after his death.

The aim of this article is to present the influence of Codreanu's political myth on contemporary Polish nationalist groups. The research on the described issue is based on content analysis and narrative analysis. The religious nature of Codreanu's ideas makes it legitimate to analyze his influence on the thought of Polish groups that belong to the category of Christian nationalism. For obvious reasons, this influence is not noticeable in the thought of neo-pagan groups such as Zadruga or Niklot. The groupings most frequently referring to Codreanu are: National Revival of Poland (Polish: Narodowe Odrodzenie Polski, short: NOP), All-Polish Youth (Polish: Młodzież Wszechpolska, short: MW), NationalRadical Camp (Polish: Obóz Narodowo-Radykalny, short: ONR), and Falanga. The research assumptions require asking a number of questions which will help understand the reasons for the popularity of Codreanu's thought among Polish as well as European nationalist groups. The most important questions to be answered are: Which elements of the legionary idea determine its popularity within contemporary Polish nationalism? What role does Codreanu's political myth play in the discourse of contemporary Polish nationalists? Is the formula of mystical nationalism proclaimed by him compatible with Christianity? Answering these questions requires the use of the method of qualitative content analysis and narrative analysis of the groups discussed.

Codreanu's legionary idea, despite its Orthodox character, has been a source of inspiration for Christian nationalist groups ever since, as evidenced by its widespread reception in contemporary Polish nationalism. Despite its strong connection to Orthodoxy, its conformity to Christian doctrine is questionable. Many of its assumptions make it similar to the Volkist circles found in Germany at the turn of the $20^{\text {th }}$ century (Halban, 2018, p. 136). In Codreanu's case, we can talk about the adaptation of Orthodoxy to the requirements of nationalist ethics. 
The research so far allows us to assume that the political myth of Codreanu is one of the most popular personal myths in the discourse of contemporary Polish nationalist groups. It is also a good example of the functioning of a modern political myth in the conditions of network society.

Academic studies on Codreanu to date have been mostly historical works with a lack of political analysis. These works have focused on the history of the movement and the biography of the leader, political doctrine, orthodox specificity of the legionary movement, anti-Semitism, or acts of political terror. The only Polish study on the history of the legionary movement is the book Żelazny Legion Michała Archanioła. $Z$ dziejów ruchu faszystowskiego w Rumunii [The Iron Legion of Archangel Michael: From the History of the Fascist Movement in Romania] by Tadeusz Dubicki and Krzysztof Dach (1996). A biographical book written in 2017 by Romanian journalist Tatiana Niculescu, The Mystic with a Revolver: Corneliu Zelea Codreanu, is another one on the leader of the Iron Guard (Polish edition - 2019). The same is true of English-language publications on Codreanu - biographical works dominate, such as Romanian Far-Right. A Sequence: Corneliu Zelea Codreanu's Case (1899-1938) by Sandache Cristian.

\section{POLITICAL MYTH AS A DYNAMIC REALITY}

The basic issue for further consideration is to define the theoretical framework of the concept of political myth. The first conception of political myth was presented by Georges Sorel in 1906 Reflections on Violence. According to the French thinker, political myth emerges when language alone proves insufficient to mobilize the social masses. For effective agitation, images must be used to achieve a guaranteed effect: "It is necessary to have recourse to the totality of images which, taken together and through intuition alone before any rational analysis, are capable of moving the mass of human feeling". Although, in Sorel's terms, a myth is a means of influencing the present, it must present a vision of some kind in order to be effective: "Experience proves to us that the constructions of a certain undetermined future in time can have great efficacy and very few defects provided they are created in a certain way" (Sorel, 2014, pp. 121-125). Sorel, being aware that in retrospect such constructs may be judged illusory, felt it necessary to use these "action-stimulating images" (2014, p. 150).

Ernst Cassirer, in his preface to An Essay on Man, emphasized the wide reception of Sorel's theory in the early $20^{\text {th }}$ century. He cited a passage from Thomas 
Mann's Doctor Faustus where the latter described Sorel's book as the book of the epoch (Cassirer, 1998, p. 9). Mann described political myths as outlandish fictions that can become dynamic reality (1960, p. 481). Cassirer considered the issue of myth through the lens of the theory of symbolic forms, according to which the key to understanding man is the symbol (Pawlik, 2016, pp. 81-82). According to Cassirer, man no longer lives exclusively in the physical world but his activities find expression in the world of symbolic forms. "The components of this world are language, myth, art and religion. These are the various threads from which this symbolic web, the tangled web of human experience, is woven" (Cassirer, 1998, pp. 69-70). With the development of man's culture-creating activity, he has been surrounded by linguistic forms, artistic images, religious or mythical symbols to such an extent that he can no longer know the world without the mediation of this artificial means.

From the perspective of his later experiences, namely anti-Semitic persecution and his escape to the United States, Cassirer developed his theory in The Myth of the State, published in 1946. Therein he saw the transformation of myth under the influence of technological development. After 1933, political myth became a consciously used tool, and "real remilitarization began with the birth of political myths" (Cassirer, 2006, p. 313). As Robert Pawlik noted, this is when the archaic form of thought which is myth fused with the modern technology of mass media. The myth, in Cassirer's terms, became not a superstructure but the base of National Socialism (2016, p. 82).

\section{THE LEGIONARY MOVEMENT}

The ideology created by Codreanu was a unique example of the fusion of politics in its most radical nationalist form with religion. The Orthodoxy professed by Codreanu was specific, often characterized by pre-Christian folk superstitions. The nationalism of the Iron Guard, often reduced to a regional variation of fascism, provides a unique example in political science of the shaping of the political doctrine of nationalism by religious principles.

Corneliu Zelea Codreanu was born on September 13, 1899 in Iași, where the family had moved from the Austro-Hungarian Bukovina. Ion, the father of the future founder of the Legion of the Archangel Michael, bore the surname Zielinski Codreanu, only to change it to Zelea Codreanu shortly before the birth of his son. Corneliu's mother - Eliza Brunner - was of German descent. Codreanu's 
Polish-German origin was often pointed out by his political opponents. Codreanu maintained that the Polish surname of his ancestors was a result of conforming to Austro-Hungarian administrative regulations. In the aforementioned book, the eminent Romanian history expert T. Dubicki wrote that according to the files collected by the Romanian Securitate, Codreanu had Polish ancestry on his father's side. This would not be surprising considering the ethnic composition of Bukovina at the time (Dubicki \& Dach, 1996, p. 16).

In the fall of 1919, Codreanu began studying at the Faculty of Law of the University of Iași. During this time the future leader of the Iron Guard began to become involved in politics. Romanian universities, like universities throughout Europe, became the arena of an ideological clash between socialist views and the developing Romanian nationalism during these years. The formula of orthodox nationalism seemed uniquely suited to a new group of students - those coming from families of inferior material status, often from the countryside, who had been allowed to study by the development of higher education in post-war Romania. They constituted a group with conservative and patriotic views as well as strong ties to the Orthodox religion established by generations of traditional upbringing.

The first political group Codreanu belonged to was the one founded in 1922 by Alexandru C. Cuza, the National Christian Defense League (Romanian: Liga Apărării Național Creștine, LANC). In 1927, Codreanu and a group of his closest associates founded the Legion of the Archangel Michael, a group that was intended to be a completely new quality among nationalist groups. More than a political group, the Legion resembled a kind of a knightly order. Compared to other European nationalist groups, a strong link to the monarchical tradition was characteristic. However, this did not result in the approval of the then monarch Charles II. He was accused of being influenced by his mistress Elena Lupescu. The fact of Lubescu's Jewish descent was, in the eyes of the legionaries, an additional accusation against the king. Codreanu (1996) wrote that the Legion's primary tasks included defending the altar and the Romanian throne. In 1930, within the Legion of the Archangel Michael, which had become a mass organization on a Romanian scale, a group was formed to create the vanguard of the Legionary Movement, the Iron Guard.

The nationalism of the political group created by Codreanu was characterized by an unusually strong mystical and religious element. The Orthodox faith was natural to Romanian nationalism but Codreanu, understanding the ethnic and religious diversity of Romania, relied on a kind of supra-confessional national 
Christianity. The Legion of the Archangel Michael included Romanians belonging to both the Orthodox Church, Greek Catholics, Catholics and Protestants. Niculescu, in her biography of Codreanu, wrote of the educational formula he encountered while attending a military high school; it was to be characterized by a combination of strong religiosity, strict moral principles, nationalism combined with a worship of the monarchy and an equal emphasis on both intellectual and physical education (2019, pp. 28-29). As Niculescu notes, a characteristic feature of Codreanu's writings is the appeal to the Christian faith, not specifically to the Orthodox Church and Orthodoxy. Inspired by the views of his father, Ion Zelea Codreanu, the specific religiosity of the Legion's leader was characterized by the penetration of numerous national elements, which he expressed in his main work For My Legionaries. The book was published in English nationalist publications in Western Europe and in the United States.

Certain characteristic features of the Legion doctrine such as the strongly developed cult of ancestors, blood and soil, brought the movement close to the Volkist ideas popular in Germany at the turn of the twentieth century which Codreanu must have encountered during his interrupted studies in Leipzig. This process was described as the "Germanization of Christianity", in effect removing those elements of the Christian ethics that did not correspond to the militant character of twentieth-century nationalism. Representatives of the "Germanized Christianity" avoided Judaic elements and, sometimes, questioned even the Jewishness of Christ (Halban, 2018, p. 136). Similar efforts to adapt Christianity to the needs of a national ethics were evident in the Legion movement. Also, the attempts to create a national form of Christianity uniting all Romanians allow this process, analogous to "Germanization", to be referred to as the "Romanization of Christianity". The Legionaries' bold interference in Christian teaching and instrumental treatment of religion as a method of educating the citizen and political soldier became a source of conflict between the Legion of the Archangel Michael and the Romanian Orthodox Church.

\section{THE RECEPTION OF THE MYTH OF CORNELIU ZELEA CODREANU IN POLAND}

Codreanu was well known to Polish nationalists already in the Interwar period. Articles about the leader of the Iron Guard appeared in "Myśl Narodowa" published in the years 1921-1939, which was linked to the National Party, and in 
"Prosto z Mostu: Literary and Artistic Weekly". Issue 21 of May 24, 1936 contains Ignacy Kleszczyński's interview with Codreanu entitled Żelazna Gwardja działa. Rozmowa z wodzem Żelaznej Gwardji Cornelio Zelea Codreanu [The Iron Guard works. Interview with the Commander of the Iron Guard Cornelio Zelea Codreanu]. The author emphasizes the youthful character of the movement, asks about the history of the group and the Romanian-Polish relations. Codreanu speaks about the mission of his generation. He mentions three tasks of the Iron Guard: to restore the national spirit, to strengthen the physical strength of the nation, and to regain the Jewish-dominated trade (Kleszczynski, 1936). Issue 54 of December 11, 1938, published shortly after Codreanu's death, contains an article entitled Ten, który byt nadzieja Rumunii [He Who Was Romania's Hope] on the front page. Kleszczynski (1938), in an article that was a tribute to the Captain, describes him as the best son of Romania, who represents the youthful ideal of religiosity and sacrifice, and the one who understands the needs of his homeland like no one else before.

Codreanu's political myth, however, found its way into the political thought of contemporary Polish nationalist groups in a different way. Apart from France, which was the place of settlement of many Romanian emigrants often with a legionary background, such as Mircea Eliade or Emil Cioran, Codreanu's thought was popular in the Italian neo-fascist underground. Given the rise of interest in integral traditionalism or the Conservative Revolution in national circles, the figure of Julius Evola appears particularly significant. Evola's thought inspired both the post-war neo-fascist movement in Italy and a number of nationalist groups throughout Europe. It is interesting to note that the person who led to Evola's meeting with Codreanu at the Green House in Bucharest was Eliade.

The current of contemporary European nationalism, i.e., tercerism, emerged from this source. The main figure of tercerism was Italian Roberto Fiore, the leader of Forza Nuova and one of the founders of the International Third Position movement. This "nationalist international" included, among others, the Romanian New Right. Contacts between European Tercerists and the National Revival of Poland (Polish: Narodowe Odrodzenie Polski, short: NOP) date back to 1992 when one of the movement's leaders, Derek Holland, came to Poland invited by domestic nationalists (Meller \& Radomski, 2014, p. 71).

The first references to Legionary thought in contemporary Polish nationalism appeared in the journalism of the National Rebirth of Poland founded in 1981. The group's leader, Adam Gmurczyk, wrote in the introduction to Żelazna Gwardia that when he first came across a mention of Codreanu as a teenager he was captivated by the simplicity of the message preached by the Legionar- 
ies. Gmurczyk saw in the figure of Codreanu a bridge that connected Polish nationalism of the late $1980^{\text {s }}$ to the rest of the nationalist world. "Codreanu became, figuratively speaking, the international language we spoke: we, European nationalists". According to the NOP president, the Legion idea helped to avoid the statolatry typical of the $1930^{\text {s }}$ by promoting the primacy of spiritual values. Gmurczyk wrote: "The Captain and his work left a clear mark on Western European nationalist movements in the last two decades of the $20^{\text {th }}$ century. The mythology of the Iron Guard and its clear spirituality resulted in the Christianization of nationalism in Western Europe" (Gmurczyk, 2016, pp. 3-4). In 1993, the NOP-linked Norwid Institute published the text by one of the leaders of the International Third Position, Derek Holland's Political Soldier. Declaration, where he wrote: "In our age, the most outstanding example of political soldiers is the Legionary movement - the Romanian Iron Guard founded and shaped by Codreanu. The spirit that animated this movement was so strong, so compelling, that during its 15 years of activity, the Iron Guard encompassed the entire nation with its influence" (Gmurczyk, Holland, \& Doboszyński, 2013, p. 34).

Bogdan Kozieł, an activist from the Silesian NOP structures and a translator of Codreanu's works, was involved in promoting the Legion idea. The group's periodical "Szczerbiec", available in public circulation since 1991, contained numerous references to Codreanu's political thought. The most important of Kozieł's publications was Wysłannik Archanioła [The Archangel Envoy] printed in parts in "Szczerbiec" and consisted of five chapters (Kozieł, 1995-1996). This text presents Codreanu's biography and the main ideological premises of the legionary movement. The first Polish translation of Droga Legionisty [The Way of the Legionnaire] by Kozieł also appeared in Szczerbiec. Publications about Iron Guard appeared many times on the website connected with NOP - nacjonalista. pl. In 2016, the Norwid Institute, associated with the group, published a collection of publications entitled Żelazna Gwardia with an introduction by Gmurczyk. The volume included publications such as Droga Legionisty [The Way of the Legionnaire] and Dziennik więzienny [The Prison Diary] by Codreanu, an interview with Codreanu published in "Prosto z Mostu" and the text He Who Was Romania’s Hope by Kleszczyński, an interview by Maria Rutkowska Codreanu - wódz odrodzonej Rumunii [Codreanu: The Leader of a Reborn Romania] published in 1938, and an interview with Elena Ilinoiu entitled Duchowy portret Codreanu. Rozmowa z Elena Codreanu, wdowa po Kapitanie [Spiritual Portrait of Codreanu: A Conversation with the Captain's Widow] by Claudio Mutti (all collected in: Gmurczyk, 2016). 
Another Polish group which referred to the myth of Codreanu was AllPolish Youth (Polish: Młodzież Wszechpolska, short: MW) founded in 1989. The organization, although less radical than NOP, also published The Way of the Legionnaire in the pages of "Training Notebooks". References to the myth of Codreanu also appeared in social media where MW activists quoted the leader of the Legion of the Archangel Michael on the occasion of commemorations of the anniversary of his death. Interestingly, Krzysztof Bosak, who has been associated with MW for years and who was a candidate for the President of Poland in 2020, has also admitted his fascination with Codreanu on social media. In 2013, on his Facebook profile he wrote: "Today is the anniversary of the murder of Corneliu Codreanu, the founder of Romania's Iron Guard, who made a big impression on me during my first years at university. According to the left, his movement is one of the varieties of Central European fascism; according to the conservativenationalist right, it is one of the most fascinating examples of a radical reaction to the modern decadence of Western politics".

In 1993, another of the groups referring to the traditions of pre-war Polish nationalism, the National-Radical Camp (Polish: Obóz Narodowo-Radykalny, short: ONR) was founded. Also in the case of ONR, the number of references to Codreanu is significant. The website Kierunki.info run by ONR activists was the place where many texts about the founder of the Legion of the Archangel Michael were published. In the formative publication Obóz idei i czynu [The Camp of Ideas and Deeds], Filip Bator (2015a) wrote: "In the history of the national movement there have often been two extreme tendencies - idle talk, thinking without doing, and action without thinking, rushing headlong into the sun. It's time to put an end to that and make us become a camp of action based on a thoughtful idea. As the leader of the Romanian nationalist movement Codreanu wrote: 'Deeds, not words! Do not say what needs to be done, but do it"'. In the text Satysfakcja w radości walki [Satisfaction in the Joy of Struggle], the same author wrote about the rise in popularity of the national idea and the attempts of the political establishment to exploit this tendency, and citing Codreanu's example, he called for a readiness to suffer and to derive satisfaction from the struggle itself and sacrifice for the national cause (Bator, 2015b). Another publication invokes, reminiscent of the Volkist influence already mentioned, the concept of nation according to Codreanu, which includes all members of the nation living now, the souls of the dead, the graves of the ancestors, and all members of the nation who will be born in the future (Bator, 2016). The biographical publications Wysłannicy Archanioła Michała [The Emissaries of Archangel Michael] by Piotr 
Puciński (2016) and Historia Legionu Archanioła Michała [The History of the Legion of the Archangel Michael] by Dominik Piekarz (2018) also supplement the material on the leader of the Legion.

Another Polish group referring to the figure of the Iron Guard leader is the Falanga, founded by former Mazovian ONR activist Bartosz Bekier. Although the group is not numerous, its activists often engage in international actions such as the visit to Donbass where the Falanga activists clearly sided with the pro-Russian separatists, or in Syria where they expressed support for the government forces of President Bashar al-Assad. Falanga activists run the Xportal. pl website where among national-radical journalism, articles on Eurasianism, integral traditionalism and the Conservative Revolution, there are also numerous publications about Codreanu.

An excerpt from Codreanu's major work For My Legionnaires was published on the website Xportal.pl in 2012. Therein, Codreanu presents the disastrous influence of democracy on the condition of the Romanian people. The negative factors Codreanu sees in democracy are: breaking the unity of the nation, equalizing the political rights of Romanians with the Jewish minority and subservience to large business. In 2013, the website published an interview with Forza Nuova leader Fiore conducted in Damascus during the International Third Position's campaign in support of Bashar al-Assad's government. When asked about his ideological inspirations, Fiore replied: "Everything that falls within the concept of the Third Position. We have always been inspired by movements and figures from the Interwar period like Codreanu, Falanga and the Carlist movement in Spain, most of the heritage of Italian fascism, but I must also mention Peronism". All of the sources of inspiration are supposed to be connected by their opposition to the materialist ideologies of liberalism and Marxism (Xportal.pl,2013).

\section{CONCLUSIONS}

The presented research results obtained by analyzing the content of contemporary Polish nationalist groups allow us to confirm the thesis that Codreanu's political myth is the most popular among personal myths used by Polish nationalists. The Christian character of the groups described is a decisive factor in the particular popularity of Codreanu's ideas. It is not reflected in the program documents of these groups, where references to the pre-war tradition of Polish nationalism 
predominate. This is probably influenced by the specificity of political myth as a form that reaches its audience through other channels. Currently, these channels are the Internet and social media, which provide a favorable ground for the symbolic form that is political myth. Additionally, Codreanu's political myth, allowing for the interpretation in the light of theoretical assumptions of Sorel, or Cassirer, is a clear exemplification of the functioning of modern political myth in the conditions of contemporary network society. An analysis of the impact of Codreanu's myth on contemporary nationalist journalism allows us to conclude that the formula of mystical nationalism, by moving away from orthodoxy towards a supra-confessional form of national Christianity, has allowed it to adapt to diverse national and religious conditions, as evidenced by the wide reception of Codreanu's thought on the grounds of nationalism both in Poland and other countries such as Italy, France, and Spain. It is clear that the contemporary political myth of Codreanu is no longer the same myth that was cultivated by the Legionaries immediately after the death of the leader of the Iron Guard. It is now used in a specific way to mobilize supporters of radical nationalism, to encourage sacrifice for the cause and to justify the costs incurred in the name of acting for the cause. Its ascetic nature is no longer so clearly emphasized.

It is symptomatic that in the case of the two most notorious acts of political terror in recent years, such as the attack on the counter demonstration of anti-fascists in Charlottesville or the shooting at mosques in Christchurch, their perpetrators or people directly associated with them, manifested a fascination with the figure of Codreanu. During the "Unite the Right" demonstration in defence of a statue of General Robert E. Lee in the college town of Charlottesville organized by the alt-right, James Alex Fields drove his car into a counter demonstration of left-wing activists killing one person and injuring about thirty. Matthew Heimbach, one of the organizers of the demonstration, appeared outside the courthouse wearing a t-shirt with the image of Corneliu Codreanu. In turn, the assassin from Christchurch - Brenton Tarrant - among the numerous names of nationalists with which he decorated his weapon also placed the symbol of the Iron Guard in a special place - on the sight of the assault rifle.

The above observations are undoubtedly a contribution to take a closer look at Codreanu's political myth on the ground of science, especially the mechanism of mobilizing supporters for political violence with the help of modern political myths. The results of the analysis conducted allow us to question the real 
Christian character of the ideology of the Legion of the Archangel Michael, which used the religious factor instrumentally in order to build a formula of mystical nationalism, far from the Christian ethics.

\section{ReFERENCES:}

Bator, F. (2015a). Obóz idei i czynu. Retrieved March 2021 from: https://kierunki.info. pl/oboz-idei-i-czynu/.

Bator, F. (2015b). Satysfakcja w radości walki. Retrieved March 2021 from: https:// kierunki.info.pl/satysfakcja-w-radosci-walki/.

Bator, F. (2016, October 7). Pojęcie narodu według Corneliu Zelei Codreanu. Retrieved March 2021 from: https://kierunki.info.pl/filip-bator-pojecie-narodu-wedlugcorneliu-zelei-codreanu/.

Blumenberg, H. (2009). Praca nad mitem. Warszawa: Oficyna Naukowa.

Cassirer, E. (1998). Esej o człowieku. Warszawa: Czytelnik.

Cassirer, E. (2006). Mit państwa. Warszawa: Wydawnictwo IFiS PAN.

Codreanu, C. (1998). Droga Legionisty. Szczerbiec, 85/86.

Codreanu, C. (1996). Legion Michała Archanioła. Fronda, 6.

Codreanu, C. (2012, January 3). Kilka uwag na temat demokracji. Retrieved April 18, 2020 from: http://xportal.pl/?p=1708.

Dubicki, T., \& Dach, K. (1996). Żelazny Legion Michała Archanioła. Z dziejów ruchu faszystowskiego w Rumunii. Warszawa: Oficyna Wydawnicza Adiutor.

Gmurczyk, A. (Ed.) (2016). Żelazna Gwardia. Warszawa: Instytut Norwida.

Gmurczyk, A., Holland, D., \& Doboszyński, A. (2013). Polityczny żołnierz. Podręcznik narodowego radykała. Warszawa: Instytut Norwida.

Halban, L. (2018). Religia starogermańska i jej aktualne znaczenie w Niemczech. In: B. Grott, \& O. Grott (Eds.). Przedhitlerowskie korzenie nazizmu, czyli dusza niemiecka w świetle filozofi i religioznawstwa (pp. 121-189). Warszawa: Wydawnictwo von Borowiecky.

Kleszczyński, I. (1936). Żelazna Gwardja działa. Rozmowa z wodzem Żelaznej Gwardji Cornelio Zelea Codreanu. Prosto z Mostu. Tygodnik literacko-artystyczny, 2(21), 5-6. Retrieved April 17, 2020 from: https://crispa.uw.edu.pl/object/files/415638/ display/Default.

Kleszczyński, I. (1938). Ten, który był nadzieją Rumunii. Prosto z Mostu. Tygodnik literacko-artystyczny, 4(54), 1. Retrieved March 2021 from: https://crispa.uw.edu. pl/object/files/415500/display/Default.

Kozieł, B. (1995-1996). Wysłannik Archanioła. Szczerbiec, 48/49, 50/51, 52/53.

Meller, A., \& Radomski, G. (2014). Nacjonalista, radykał czy ekstremista? Publicystyka Adama Gmurczyka - lidera Narodowego Odrodzenia Polski (1994-2005). Athenaeum. Polskie Studia Politologiczne, 41, 58-76. 
Mutti, C. (2016). Duchowy portret Codreanu. Rozmowa z wdową po Kapitanie. In: A. Gmurczyk (Ed.). Żelazna Gwardia. Warszawa: Instytut Norwida.

Niculescu, T. (2019). Mistyk z rewolwerem. Corneliu Zelea Codreanu. Kraków: Universitas.

Pawlik, R. (2016). Cassirer i Blumenberg. O możliwości odmitologizowania polityki. Przeglad Polityczny, 136, 80-87.

Piekarz, D. (2018, June 24). Historia Legionu Archanioła Michała. Retrieved March 2021 from: https://kierunki.info.pl/dominik-piekarz-historia-legionu-archaniolamichala/.

Pisarski, M. (2015). Mistyczny nacjonalizm Corneliu Zelea Codreanu. In: R. Michalak (Ed.). Polityka jako wyraz lub następstwo religijności (pp. 251-260). Sieniawa Żarska: Wydawnictwo Morpho.

Puciński, P. (2016, September 1). Wysłannicy Archanioła Michała. Retrieved March 2021 from: https://kierunki.info.pl/piotr-pucinski-wyslannicy-archaniola-michala/. Rutkowska, M. (2016). Codreanu - wódz odrodzonej Rumunii. In: A. Gmurczyk (Ed.). Żelazna Gwardia. Warszawa: Instytut Norwida.

Sorel, G. (2014). Rozważania o przemocy. Warszawa: Wydawnictwo Krytyki Politycznej. Xportal.pl (2013, June 24). Dla Xportalu: Roberto Fiore. Retrieved March 2021 from: http://xportal.pl/?p=9083. 